\title{
Mass balance-based plant-wide wastewater treatment plant models - Part 4: Aerobic digestion of primary and waste activated sludges
}

\author{
SW Sötemann, MC Wentzel and GA Ekama*
}

Water Research Group, Department of Civil Engineering, University of Cape Town, Rondebosch 7701, Cape, South Africa

\begin{abstract}
From a theoretical investigation of the continuity of wastewater organic (COD) and $\mathrm{N}$ compounds along the links connecting the primary settling tank (PST), fully aerobic or N removal activated sludge (AS) treating raw and settled wastewater and aerobic digestion unit operations, it was found that the PS characteristics, viz. the biodegradable and unbiodegradable soluble and particulate $\mathrm{COD}$ and $\mathrm{N}$ concentrations, need to be calculated from mass balances around the PST so that the organic and $\mathrm{N}$ concentrations conform to continuity principles. Also, it can be accepted that the influent wastewater (fixed) inorganic suspended solids (ISS) concentration is conserved through the primary settling tank, activated sludge, aerobic digestion systems. However, the measured ISS flux at different stages through a series of wastewater treatment plant (WWTP) unit operations is not equal to the influent ISS flux because the OHO biomass contributes to the ISS flux by differing amounts depending on the active fraction of the VSS solids at that stage. The steady state activated sludge and aerobic digestion models, both modified to include the inorganic suspended solids (ISS) and the latter to include aerobic digestion of primary sludge, yielded virtually identical results as Activated Sludge Model No 1 (ASM1), also modified to include the ISS. This research shows that the mass balance-based steady state activated sludge and aerobic digestion models, modified to include the ISS compound, can be coupled to produce a plant-wide WWTP model for aerobic stabilisation of sludge that can be used for design and operation and checking of simulation model results.
\end{abstract}

Keywords: wastewater treatment, primary sludge, waste activated sludge, aerobic digestion, model validation

\section{List of abbreviations}

AD anaerobic digestion

ADM1 Anaerobic Digestion Model No. 1

AerD aerobic digestion

Alk alkalinity with respect to the $\mathrm{H}_{2} \mathrm{CO}_{3} *$ reference species

ADWF average dry weather flow

AS activated sludge

ASM1,2,3 Activated Sludge Models No. 1, 2 or 3

BEPR biological excess phosphorus removal

BNR biological nutrient removal

C carbon

${ }^{\circ} \mathrm{C} \quad$ degrees Centigrade

$\mathrm{Ca} \quad$ calcium

COD chemical oxygen demand

d day

$\mathrm{Eq} \quad$ equation

FSA free and saline ammonia

$\mathrm{H}$ hydrogen

ISS inert suspended solids

$\mathrm{K} \quad$ potassium

$\ell \quad$ litres

$\mathrm{Mg}$ magnesium

$\mathrm{N} \quad$ nitrogen

ND nitrifying - denitrifying

NDBEPR nitrifying - denitrifying biological excess phosphorus removal

* To whom all correspondence should be addressed.

喕 +2721650 2588; fax: +27 21689 7471;

e-mail: ekama@ebe.uct.ac.za

Received 5 August 2005; accepted in revised form 28 April 2006.
$\mathrm{O}$

$\mathrm{OHO}$

OP

OrgN

OTR

OUR

$\mathrm{P}$

PAO

$\mathrm{pH}$

PS

PST

Q

$\mathrm{R}$

RBCOD

SBCOD

SOUR

SS

TKN

TP

TSS

V

VFA

VSS

VS

WAS

WW

WWTP

\section{oxygen}

ordinary heterotrophic organism

ortho-phosphorus

organic nitrogen

oxygen transfer rate

oxygen utilisation rate, subscripts $\mathrm{c}, \mathrm{n}$ and $\mathrm{t}$ denote carbonaceous, nitrification and total

phosphorus

phosphorus accumulating organism

negative log of the hydrogen ion activity

primary sludge

primary settling tank

flow

hydraulic retention time or sludge age for anaerobic digester

readily biodegradable COD

slowly biodegradable COD

specific oxygen utilisation rate $(\mathrm{mgO} /(\mathrm{gVSS} . \mathrm{d})$.

Subscripts $\mathrm{c}, \mathrm{n}$ and $\mathrm{t}$ denote carbonaceous, nitrification and total.

settleable solids

total Kjeldahl nitrogen

total phosphorus

total suspended solids

volume

volatile fatty acids

volatile suspended solids

volatile solids

waste activated sludge

wastewater

wastewater treatment plant 


\section{List of symbols}

$b_{H}, b_{H} \quad$ OHO endogenous respiration and death rates (/d). Additional subscripts $\mathrm{T}$ and 20 denote rates at $\mathrm{T}$ and $20^{\circ} \mathrm{C}$

$f_{a v} f_{a t} \quad$ OHO fraction of AS with respect to VSS and TSS Additional subscripts i or e denote aerobic digester influent or effluent.

$f_{c} \quad$ Carbon to VSS ratio of particulate organics

$f, f_{c P S S} \quad \mathrm{COD} / \mathrm{VSS}$ ratio of AS and PS

$f_{E H} f_{E H}^{\prime} \quad$ unbiodegradable fraction of OHOs in endogenous respiration and death regeneration models

$f_{i}, f_{i i}, f_{i e} \quad$ VSS/TSS ratio of AS. Subscripts i and e denote influent and effluent sludge. Subscript PS refers to primary sludge.

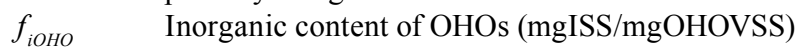

$f_{n}, f_{n P S} \quad$ Nitrogen fraction of AS and PS (mgN/mgVSS)

$f_{n a} \quad$ Fraction of influent TKN that is FSA

$f_{n u} \quad$ Fraction of influent TKN that is unbiodegradable soluble $\operatorname{OrgN}$

$f_{P S R} \quad$ Fraction of COD removed by primary sedimentation

$f_{p}, f_{p P S} \quad$ Phosphorus fraction of AS (mgP/mgVSS).

Additional subscript PS denotes primary sludge

$f_{A S^{\prime} u p}, f_{P S^{\prime} u p}$ Fraction of unbiodegradable COD in AS and PS

$f_{S b}$ 's $\quad$ Influent RBCOD fraction with respect to the biodegradable COD

$f_{\text {Sup }}, f_{\text {Sus }} \quad$ Particulate and soluble unbiodegradable COD fraction of wastewater.

Additional subscript $\mathrm{R}$ and $\mathrm{S}$ denote raw and settled wastewater.

$f_{v s r}, f_{t s r} \quad$ Fraction of VSS and TSS removed in aerobic digestion.

$f_{X B G P} \quad$ P content of PAOs (mgP/mgPAOVSS)

$f_{Z B, N} f_{Z B, P} \quad \mathrm{~N}$ and $\mathrm{P}$ content of OHOs (mgN or mgP per gOHOCOD)

$N_{a i} \quad$ Influent ammonia (FSA) concentration $(\mathrm{mgN} / \mathrm{l})$

$N_{o b p i}^{a i}, N_{o b s i}$ Influent biodegradable particulate and soluble OrgN concentration ( $\mathrm{mgN} / \mathrm{l}$ )

$N_{\text {oupi }}, N_{\text {ousi }}$ Influent unbiodegradable particulate and soluble OrgN concentration $(\mathrm{mgN} / \mathrm{l})$

$O \quad$ Oxygen utilisation rate $[\mathrm{mgO} /(\ell \cdot \mathrm{h})]$. Subscripts c, $\mathrm{n}$ and $t$ denote carbonaceous, nitrification and total

$p_{\mathrm{CO} 2} \quad$ Partial pressure of $\mathrm{CO}_{2}$

$Q_{i} \quad$ Influent flow $(\ell / \mathrm{d})$

$R_{h} \quad$ Hydraulic retention time (d)

$R_{s} \quad$ Sludge age (d)

$R^{2} \quad$ Correlation coefficient

$S_{b p} \quad$ Biodegradable particulate organics concentration $(\mathrm{mgCOD} / \mathrm{l})$

$S_{b p i}, S_{b s i} \quad$ Influent biodegradable particulate and soluble COD concentrations $(\mathrm{mgCOD} / \ell)$

$S_{t i}, S_{t e} \quad$ Total influent and effluent COD concentration $(\mathrm{mgCOD} / \mathrm{l})$

$S_{u p i}, S_{u s i} \quad$ Influent unbiodegradable particulate and soluble COD concentrations $(\mathrm{mgCOD} / \ell)$

$V_{d} \quad$ Volume of digester

$X_{B H}^{d} \quad$ OHO biomass concentration $(\mathrm{mgVSS} / \mathrm{\ell})$

$X_{E H} \quad$ OHO endogenous residue concentration $(\mathrm{mgVSS} / \mathrm{l})$

$X_{P}, X_{I i} \quad$ Unbiodegradable organics concentration in reactor

$X_{I o}, X_{I o i} \quad$ ISS (fixed and biomass) concentration in reactor (mgISS/ $/$ ). Additional subscript i denotes influent.

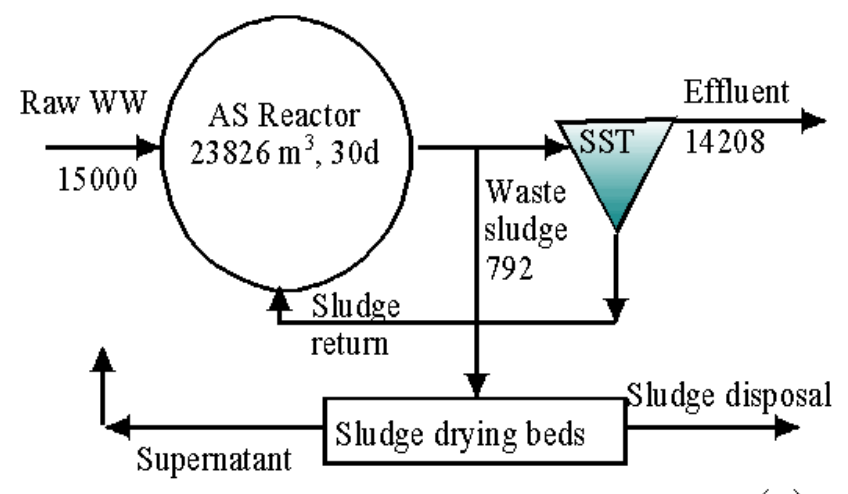

Flows in $\mathrm{m}^{3} / \mathrm{d}$ (a)

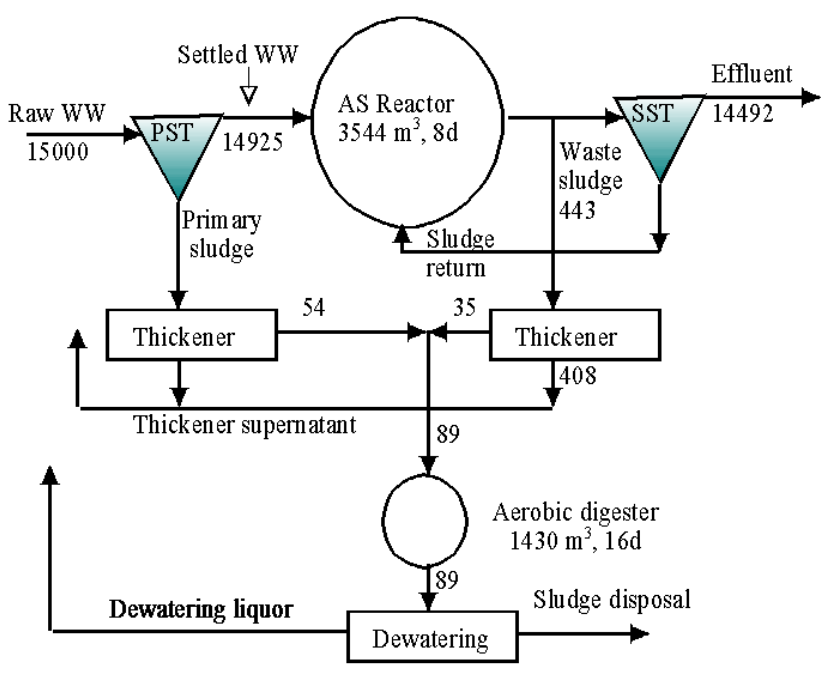

Flows in $\mathrm{m}^{3} / \mathrm{d}$

(b)

Figures $1 \mathrm{a}$ and $1 \mathrm{~b}$

Wastewater treatment plant schemes treating (1) raw wastewater at a long sludge age (extended aeration) (Fig. 1a) and (2) including primary settling tank, short sludge age activated sludge system and aerobic digestion of primary and waste activated sludges (Fig. 1b) analysed with the steady state activated sludge and aerobic digestion models and simulated with ASM1 (Thickener supernatant and dewatering liquor recycling not simulated).
$X_{v}, X_{v i}, X_{v e}$ VSS concentration (mgVSS/l). Additional subscript $i$ and e denote influent and effluent.
$X_{t}, X_{t i}, X_{t e}$ TSS concentration (mgTSS/ $\ell$ ). Additional subscript $i$ and e denote influent and effluent.
$Y_{H} \quad$ OHO yield coefficient (mgVSS/mgCOD)
$\alpha, \beta, \gamma, \delta \quad$ substitution variables in VSS and TSS based steady state AerD model
4.57 mgO required per mgFSA-N nitrified to nitrate

\section{The primary settling tank (PST) - aerobic digester link}

Having established that the unbiodegradable particulate COD fraction of primary sludge (PS) ( $\left.f_{\text {PS'up }}\right)$ can be calculated from a mass balance around the primary settling tank (PST, Wentzel et al., 2006, Part 1), the PS - Aerobic digester (AerD) link was investigated by modelling two wastewater treatment plant (WWTP) schemes (Fig. 1):

- An extended aeration activated sludge system treating raw wastewater at a very long sludge age (30 d) (Fig. 1a) and

- treating the same raw wastewater a PST-settled wastewater 


\begin{tabular}{|c|c|c|c|c|}
\hline \multicolumn{5}{|c|}{$\begin{array}{c}\text { TABLE } 1 \\
\text { Raw and settled wastewater and primary sludge characteristics calculated } \\
\text { from a mass balance around the primary settling tank (PST) for raw and set- } \\
\text { tled wastewater unbiodegradable particulate COD fractions }\left(f_{s^{\prime} u p}\right) \text { of } 0.15 \text { and } \\
0.04 \text { and raw wastewater soluble unbiodegradable and biodegradable COD } \\
\text { fractions }\left(f_{s^{\prime} u s} \text { and } f_{S^{\prime}{ }^{\prime} s} \text { ) of } 0.07 \text { and } 0.25 \text { respectively. }\right.\end{array}$} \\
\hline Parameter & Raw WW & Settled WW & $\begin{array}{c}\text { Primary } \\
\text { Sludge }\end{array}$ & Units \\
\hline Flow & 15000 & 14925 & 75 & $\mathrm{~m}^{3} / \mathrm{d}$ \\
\hline Total COD $\left(\mathrm{S}_{\mathrm{ti}}\right)$ & 750 & 450 & 60450 & $\mathrm{mgCOD} / \mathrm{l}$ \\
\hline Unbiodegradable particulate COD $\left(\mathrm{S}_{\mathrm{upi}}\right)$ & 112 & 18 & 18818 & $\mathrm{mgCOD} / \mathrm{l}$ \\
\hline Unbiodegradable soluble COD $\left(\mathrm{S}_{\mathrm{usi}}\right)^{4}$ & 53 & 53 & 53 & $\mathrm{mgCOD} / \mathrm{l}$ \\
\hline Biodegradable particulate COD $\left(\mathrm{S}_{\mathrm{bpi}}\right)$ & 439 & 233 & 41433 & $\mathrm{mgCOD} / \mathrm{l}$ \\
\hline Biodegradable soluble COD $\left(\mathrm{S}_{\mathrm{bsi}}\right)^{4}$ & 146 & 146 & 146 & $\mathrm{mgCOD} / \mathrm{l}$ \\
\hline Unbiodegradable COD fraction of $\mathrm{PS}^{1}$ & - & - & 0.312 & \\
\hline Total TKN $\left(\mathrm{N}_{\mathrm{ti}}\right)$ & 60 & 51.1 & 1831 & $\mathrm{mgN} / \mathrm{l}$ \\
\hline Free and saline ammonia $\left(\mathrm{N}_{\mathrm{ai}}\right)$ & 45 & 45 & 45 & $\mathrm{mgN} / \mathrm{l}$ \\
\hline Unbiodegradable particulate $\operatorname{OrgN}\left(\mathrm{N}_{\text {oupi }}\right)^{2}$ & 7.6 & 1.2 & 1281 & $\mathrm{mgN} / \mathrm{l}$ \\
\hline Unbiodegradable soluble $\operatorname{OrgN}\left(\mathrm{N}_{\text {ousi }}\right)^{3}$ & 1.8 & 1.8 & 1.8 & $\mathrm{mgN} / \mathrm{l}$ \\
\hline Biodegradable particulate $\operatorname{OrgN}\left(\mathrm{N}_{\text {obpi }}\right)^{4}$ & 3.9 & 1.4 & 501 & $\mathrm{mgN} / \mathrm{l}$ \\
\hline Biodegradable soluble $\operatorname{OrgN}\left(\mathrm{N}_{\text {obsi }}\right)^{4}$ & 1.7 & 1.7 & 1.7 & $\mathrm{mgN} / \mathrm{l}$ \\
\hline Unbiodegradable TKN fraction of $\mathrm{PS}^{1}$ & & & 0.719 & \\
\hline Total suspended solids (TSS) & 301 & 78.7 & 44459 & $\mathrm{mgTSS} / \ell$ \\
\hline Volatile suspended solids (VSS) & 253 & 69.2 & 36829 & $\mathrm{mgVSS} / \ell$ \\
\hline Inorganic suspended solids (ISS) & 48 & 9.5 & 7650 & $\mathrm{mgISS} / \ell$ \\
\hline
\end{tabular}

${ }^{1}$ Obtained from a strict mass balance - Eq. 1 in Wentzel et al. (2006, Part 1) yields 0.315 .

${ }^{2}$ Calculated from a TKN/COD ratio $\left(f_{\mathrm{ZBN}}\right)=68.6 \mathrm{mgN} / \mathrm{gCOD}$ or equivalently $\mathrm{f}_{\mathrm{n}}=0.10 \mathrm{mgN} / \mathrm{mgVSS}$ and $\mathrm{COD} / \mathrm{VSS}=1.48 \mathrm{mgCOD} / \mathrm{mgVSS}$ for the influent unbiodegradable particulate organics.

${ }^{3}$ Based on a raw wastewater FSA/TKN ratio and unbiodegradable soluble TKN fraction of $\left(\mathrm{f}_{\mathrm{na}}\right.$ and $\left.\mathrm{f}_{\mathrm{nu}}\right)$ of 0.75 and 0.03 respectively.

${ }^{4}$ Based on $0.45 \mu \mathrm{m}$ membrane filtered COD and TKN concentrations of $199 \mathrm{mgCOD} / \ell$ and $3.5 \mathrm{mgN} / \ell$, and accepting that $0.45 \mu \mathrm{m}$ membrane filtrate concentrations are soluble.

activated sludge system at a short sludge age $(8 \mathrm{~d})$ with aerobic digestion of PS and waste activated sludge (WAS) to the same residual biodegradable COD (same active fraction) as the raw wastewater system (Fig. 1b).

From mass balance principles around the two WWTP schemes, the total oxygen demand in both WWTPs should be (closely) the same if $\mathrm{f}_{\mathrm{PS} \text {,up }}$ has been determined correctly for the aerobic digester.

\section{Aerobic digestion of primary sludge - steady state modelling}

The steady state aerobic digestion model for WAS (see Table 2 in Ekama et al., 2006a, Part 2) also can be applied to stabilisation of PS. This hinges around calculating the equivalent influent active fraction of the PS, which is possible provided the $\mathrm{f}_{\text {PS' up }}$ fraction of the PS is known. The $\mathrm{f}_{\text {PS up }}$ is calculated from a mass balance around the PST. For example, in a PST in which $40 \%$ COD and $15 \%$ TKN removal are obtained for typical raw and settled wastewater characteristics listed in Table 1, the PS generated has the following characteristics: $\mathrm{f}_{\mathrm{PS} \text { 'up }}=0.314, \mathrm{COD} /$ VSS ratio $\left(\mathrm{f}_{\text {cvps }}\right)=1.64 \mathrm{mgCOD} / \mathrm{mgVSS}$, TKN (orgN)/VSS ratio $\left(\mathrm{f}_{\mathrm{pS}}\right)=0.049 \mathrm{mgN} / \mathrm{mgVSS}$, unbiodegradable particulate TKN $(\mathrm{OrgN})$ fraction $=0.59 \mathrm{mgN} / \mathrm{mgN}$ (i.e. 0.31 biodegradable $\mathrm{OrgN}$ fraction) and VSS/TSS ratio $\left(\mathrm{f}_{\mathrm{iPS}}\right)=0.83$. Unless the COD/VSS ratio of the biodegradable or unbiodegradable particulate organ- ics is known, the unbiodegradable VSS fraction in PS cannot be calculated from the raw and settled wastewater and PS characteristics.

From anaerobic digestion of PS (Wentzel et al., 2006, Part 1), it was established that the COD/VSS $\left(\mathrm{f}_{\mathrm{cv}}\right)$ and TKN/COD $\left(\mathrm{f}_{\mathrm{ZB}, \mathrm{N}}\right)$ ratios of the unbiodegradable particulate organics are higher than those for the biodegradable particulate organics, and that the ratios for the unbiodegradable particulate organics are lower than the ratios that have been assumed previously for these same organics in activated sludge (see Table 1 in Wentzel et al., 2006, Part 1). Because the implications of these differences for the activated sludge system have not been fully explored yet, the commonly accepted COD/VSS and TKN/COD ratios of activated sludge have been assumed for the unbiodegradable particulate organics in this analysis, i.e. $\mathrm{f}_{\mathrm{cv}}=1.48 \mathrm{mgCOD} / \mathrm{mgVSS}$ and $\mathrm{f}_{\mathrm{ZB,N}}=67.6 \mathrm{mgN} / \mathrm{gCOD}\left(\mathrm{f}_{\mathrm{n}}=0.10 \mathrm{mgN} / \mathrm{mgVSS}\right)$.

The biodegradable COD in PS is utilised in the aerobic digester and transformed to OHO biomass in the same way as it would be in the activated sludge system if raw wastewater were treated. The COD/VSS ratio $\left(f_{\mathrm{cv}}\right)$ of the OHO biomass formed is $1.48 \mathrm{mgCOD} / \mathrm{mgVSS}$, the same as that formed in the activated sludge system. Once the OHO biomass has formed, this is degraded via endogenous respiration (or death regeneration) in the aerobic digester in the identical way as was described by Ekama et al. (2006a, Part 2). However, one important difference is that the oxygen utilised in the digester is the sum of that used for synthesis of $\mathrm{OHO}$ biomass and for endogenous respira- 


\begin{tabular}{|c|c|c|c|c|c|c|}
\hline \multicolumn{7}{|c|}{$\begin{array}{l}\text { TABLE } 2 \\
\text { Blended primary sludge and waste activated sludge characteristics after thickening } \\
\text { PS to } \sim 6 \% \text { and WAS to } \sim 5 \% \text { TSS concentration }\end{array}$} \\
\hline \multicolumn{7}{|c|}{$\begin{array}{l}\text { Primary sludge total COD concentration } 60450 \mathrm{mgCOD} / \mathrm{l} \text { in } 75 \mathrm{~m}^{3} / \mathrm{d} \text { flow (Table 1) } \\
\text { Unbiodegradable fraction of primary sludge }\left(\mathrm{f}_{\mathrm{PS} u \mathrm{up}}\right)=0.315(\text { Eq. } 1 \mathrm{in} \text { Wentzel et al., } 2006 \\
\text { Activated sludge system: Sludge age } 8 \mathrm{~d} \text {, volume }=3544 \mathrm{~m}^{3}, \mathrm{OUR}^{1}=44.18 \mathrm{mgO} /(\mathrm{l} . \mathrm{h}) \text {, } \\
\text { wastewater characteristics in Table } 1 . \\
\text { Aerobic digester: Retention time }=16.0 \mathrm{~d} \text {, volume }=1430 \mathrm{~m}^{3}, \mathrm{OUR}^{1}=92.74 \mathrm{mgO} /(\ell . \mathrm{h})\end{array}$} \\
\hline Parameter & $\begin{array}{c}\text { PS after } \mathrm{OHO} \\
\text { synthesis }\end{array}$ & \begin{tabular}{|c|} 
PS thick \\
to $\sim 6 \%$
\end{tabular} & $\begin{array}{l}\text { WAS } \\
\text { ex AS }\end{array}$ & $\begin{array}{c}\text { WAS } \\
\text { thick to } \\
\sim 5 \%\end{array}$ & $\begin{array}{l}\text { PS+WAS } \\
\text { Blend }\end{array}$ & $\begin{array}{l}\text { Digester } \\
\text { Effluent }\end{array}$ \\
\hline Waste stream flow $\mathrm{m}^{3} / \mathrm{d}$ & 75 & 54 & 443 & 35 & 89 & 89 \\
\hline Active OHO conc $\mathrm{mg} / \mathrm{l}$ & 18634 & 25880 & 2179 & 27808 & 26638 & 6295 \\
\hline Unbiodeg VSS mg/l & 12866 & 17869 & 1122 & 14202 & 16427 & 20491 \\
\hline VSS mg/l & 31500 & 43750 & 3319 & 42010 & 43065 & 26786 \\
\hline ISS from raw WW $\mathrm{mg} / \mathrm{l}$ & 7650 & 10625 & 320 & 4050 & 8039 & 8039 \\
\hline ISS in biomass $\mathrm{mg} / \ell$ & 2795 & 3882 & 330 & 4177 & 3998 & 944 \\
\hline Total ISS mg/l & 10445 & 14507 & 650 & 8227 & 12037 & 8983 \\
\hline TSS (VSS+ISS) mg/l & 41945 & 58256 & 3970 & 50236 & 55102 & 35769 \\
\hline Active fraction (VSS) & 0.592 & 0.592 & 0.662 & 0.662 & 0.619 & 0.235 \\
\hline Active fraction ( TSS) & 0.444 & 0.444 & 0.554 & 0.554 & 0.483 & 0.176 \\
\hline VSS/TSS ratio & 0.751 & 0.751 & 0.836 & 0.836 & 0.782 & 0.753 \\
\hline Oxygen Demand kgO/d & Synthesis 1037 & & & & Total 3138 & \\
\hline
\end{tabular}

${ }^{1}$ Carbonaceous oxygen demand only. Aerobic digester OUR includes that for synthesis of OHO biomass but no nitrification. Nitrification adds about $6 \mathrm{mgO} /(\ell \cdot h)$.

tion of the formed $\mathrm{OHO}$ biomass (including nitrification, if this takes place). Accepting the soluble COD concentrations in PS as negligible (Table 1), if a fraction $\mathrm{f}_{\mathrm{PS} \text { up }}$ of the PS total particulate COD is unbiodegradable, the biodegradable fraction is $\left(1-\mathrm{f}_{\mathrm{PS}^{\prime} \text { up }}\right)$. The OHO biomass that grows from this is $\mathrm{Y}_{\mathrm{H}}\left(1-\mathrm{f}_{\mathrm{PS}^{\prime} \text { up }}\right)$ $\mathrm{kgOHOVSS} / \mathrm{kg}$ PS COD. The unbiodegradable particulate COD has the same COD/VSS ratio as this material in the activated sludge reactor treating raw wastewater, which for the purposes of this analysis is $\mathrm{f}_{\mathrm{cv}}=1.48 \mathrm{mgCOD} / \mathrm{mgVSS}$. Hence, the VSS mass of the unbiodegradable particulate organics is $\mathrm{f}_{\mathrm{PS}} / \mathrm{f}_{\mathrm{cv}} \mathrm{kgVSS} / \mathrm{kg}$ PS COD. The total VSS mass is the sum of the OHO VSS and

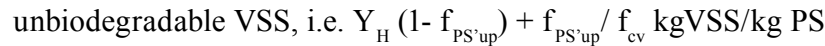
COD. The ratio of the $\mathrm{OHO}$ and total VSS masses gives the equivalent active fraction of the PS ( $\left(f_{\text {avPS }}\right)$, which is given by:

$$
\frac{1}{f_{a P S}}=1+\frac{f_{P S^{\prime} u p}}{f_{c v} Y_{H}\left(1-f_{P S^{\prime} / p}\right)}
$$

The oxygen demand for synthesis of the OHO VSS mass, $\mathrm{O}_{\mathrm{s}}$ is,

$$
V_{d} O_{s}=Q_{i} S_{t P S}\left(1-f_{c v} Y_{H}\right)\left(1-f_{P S, u p}\right) \mathrm{kgO} / \mathrm{d}
$$

where:

$\mathrm{V}_{\mathrm{d}}$ is the volume of the digester

$\mathrm{Q}_{\mathrm{i}}$ and $\mathrm{S}_{\mathrm{tPS}}$ the PS influent flow and total COD concentration respectively.

For example, for the WWTP in Fig. 1b and the wastewater characteristics in Table 1 , the primary sludge COD concentration is $60450 \mathrm{mgCOD} / \mathrm{l}$ in a flow of $75 \mathrm{~m}^{3} / \mathrm{d}$, i.e. $4534 \mathrm{kgCOD} / \mathrm{d}$. From Eq. 1 in Wentzel et al. (2006, Part 1), the unbiodegradable particulate fraction of this PS COD $\left(\mathrm{f}_{\mathrm{PS} \text { up }}\right)=0.315$. Hence the OHO VSS concentration synthesised is $0.45(1-0.315) 60450$ $=18634 \mathrm{mgVSS} / \mathrm{\ell}$, the unbiodegradable VSS concentration $=0.315 \times 60450 / 1.48=12866 \mathrm{mgVSS} / \ell$ and the total VSS concentration $=18634+12866=31500 \mathrm{mgVSS} / \ell$. The PS ISS concentration is $7560 \mathrm{mgISS} / \ell$ and the OHO ISS contribution
$($ after OHO formation $)=0.15(18634)=2795 \mathrm{mgISS} / \mathrm{l}$, making the total ISS $=10445 \mathrm{mgISS} / \ell$. Hence the TSS equals $31500+$ $10445=41945 \mathrm{mgTSS} / \ell$. From these concentrations, the active fractions of the VSS and TSS and VSS/TSS ratio are 0.592, 0.444 and 0.751 respectively (Table 2 ) and the oxygen demand for synthesis is given by Eq. (2) i.e. $0.075 \times 60450(1-1.48 \times 0.45)$ $(1-0.315)=1037 \mathrm{kgO} / \mathrm{d}$ (Table 2$)$.

By specifying an effluent active fraction $\left(\mathrm{f}_{\text {ave }}\right.$ or $\left.\mathrm{f}_{\text {ate }}\right)$, the aerobic digester retention time $\left(\mathrm{R}_{\mathrm{h}}\right)$ and oxygen demand for the $\mathrm{OHO}$ biomass breakdown are given by Eqs. (1) to (6) or (11) to (16) in Table 2 in Ekama et al. (2006a, Part 2). To this oxygen demand, the oxygen demand for synthesis must be added to give the total oxygen demand $(\mathrm{kgO} / \mathrm{d})$. From this total oxygen demand and an acceptable oxygen transfer rate [OTR, $\mathrm{mgO} /(\ell \cdot \mathrm{h})]$ of the aeration system, the volume of the digester $\left(\mathrm{V}_{\mathrm{d}}\right)$ is calculated. With the retention time $\left(R_{h}\right)$ known, the digester influent feed flow rate is determined $\left(\mathrm{Q}_{\mathrm{i}}=\mathrm{V}_{\mathrm{d}} / \mathrm{R}_{\mathrm{h}}\right)$. The ratio of the actual PS flow rate and the digester feed flow rate $\left(Q_{i}\right)$ is the degree of PS thickening required by gravity sedimentation. If the thickened TSS concentration that matches the maximum OTR is too high and cannot be achieved in the PST or gravity thickener, then $V_{d}$ will be larger and based on the PS flow rate $\left(\mathrm{Q}_{\mathrm{i}}\right)$ for the thickened TSS concentration that can be achieved, i.e. $V_{d}=Q_{i} R_{h}$. For example, if the primary sludge is to be stabilised to an active fraction with respect to VSS ( $f_{\text {ave }}$ ) of 0.235 , then from Eq. (2) $\alpha=3.455$, Eq. (1) $\beta=0.889$, Eq. (3) $R_{h}=14.3$ d, Eq. (5) $f_{v s r}=0.351$ and Eq. (6) $\mathrm{V}_{\mathrm{d}} \mathrm{O}=1.48 \times 0.352 \times 0.075 \times 31500=1230 \mathrm{kgO} / \mathrm{d}$. Adding the $1037 \mathrm{kgO} / \mathrm{d}$ synthesis oxygen demand gives the total oxygen demand $=2268 \mathrm{kgO} / \mathrm{d}$. If a maximum OTR of $125 \mathrm{mgO} /(\ell \cdot \mathrm{h})$ is accepted for the aeration system, then a digester volume of $2268 \mathrm{x}$ $1000 /(24 \times 125)=756 \mathrm{~m}^{3}$ is required. To obtain $14.3 \mathrm{~d}$ retention time, the influent flow rate $\left(Q_{i}\right)$ is $756 / 14.3=52.8 \mathrm{~m}^{3} / \mathrm{d}$. The PS thus can be thickened by $75 / 52.8=1.42$ times by gravity thickening, or to a TSS concentration (before $\mathrm{OHO}$ formation, 
from Table 1) of $44459 \times 1.42=63072 \mathrm{mgTSS} / \ell$ or $6.3 \%$ solids. Higher (or lower) maximum OTRs for the aeration system will result in smaller (or greater) digester volumes and higher (or lower) thickened digester feed concentrations.

Because the unbiodegradable TKN (and TP) fractions of PS are so much higher than the unbiodegradable COD fraction (most of the PS TKN and TP are locked up in the unbiodegradable organics (Table 1 in this paper and Table 1 in Wentzel et al., 2006, Part 1), the PS does not contain sufficient available $\mathrm{N}$ (and $\mathrm{P}$ ) for $\mathrm{OHO}$ growth. Therefore, ammonia and phosphate need to be dosed to the aerobic digester to facilitate non-nutrient deficient $\mathrm{OHO}$ growth. Because the yield of biomass under anaerobic conditions is only $1 / 10$ th of that under aerobic conditions, nutrient dosing usually is not necessary for anaerobic digestion of PS and is one of several good reasons why PS is usually anaerobically digested. In the aerobic digester, even though the synthesis process is much faster than the endogenous process, $\mathrm{N}$ and $\mathrm{P}$ are released during endogenous respiration and become available for synthesis of biomass, which reduces the $\mathrm{N}$ and $\mathrm{P}$ dose and reduces nitrification (provided $\mathrm{N}$ is not overdosed). For example, from Table 1, the ammonia and biodegradable organic nitrogen available in the PS for OHO synthesis, including the ammonia and soluble biodegradable organic $\mathrm{N}$ and taking due account of PS thickening, is $45+501 \times 1.42+1.7=$ $758 \mathrm{mgN} / \ell$. The concentration of $\mathrm{N}$ required for $\mathrm{OHO}$ synthesis at $0.10 \mathrm{mgN} / \mathrm{mgVSS}$ is $0.10 \times 18634 \times 1.42=2646 \mathrm{mgN} / \mathrm{l}$. However, $\mathrm{N}$ is released to the bulk liquid during endogenous respiration and becomes available as an $\mathrm{N}$ source for synthesis, i.e. 0.10 x $0.352 \times 31500 \times 1.42=1575 \mathrm{mgN} / \ell$ (Eq. (9) in Table 2 of Ekama et al., 2006a, Part 2). Therefore the net $\mathrm{N}$ deficit is $2646-758$ $1575=313 \mathrm{mgN} / \ell$ or $313 \times 0.054=16.9 \mathrm{kgN} / \mathrm{d}$. The P supplement, as $\mathrm{kgP} / \mathrm{d}$, is calculated the same way and is approximately between 20 to $30 \%$ of the $\mathrm{N}$ addition.

With regard to the ISS, this concentration initially increases in the aerobic digester treating PS due to OHO growth, but then decreases due to $\mathrm{OHO}$ biomass loss with endogenous respiration. The VSS/TSS ratio therefore changes from that of the influent PS value as aerobic digestion progresses. The aerobic digestion model in terms of TSS also can be used, but then the equivalent influent active fraction of the PS needs to be expressed with respect to TSS, i.e. $f_{\text {atPS }}$. The ISS concentration on which $f_{\text {atPS }}$ is based is the sum of the ISS concentration from the influent wastewater that settles out in the PST plus the ISS contribution of the $\mathrm{OHO}$ that forms. The latter is given by $\mathrm{f}_{\mathrm{iOHO}} \mathrm{Y}_{\mathrm{H}}\left(1-\mathrm{f}_{\mathrm{PS} \text { up }}\right)$ $\mathrm{S}_{\mathrm{tPS}}$. For example, from Table 1, the influent fixed ISS concentration to the PS digester is $7650 \times 1.42=10863 \mathrm{mgISS} / \ell$ in a flow of $53 \mathrm{~m}^{3} / \mathrm{d}$. The effluent fixed ISS concentration therefore also is $10863 \mathrm{mgISS} / \mathrm{l}$. However, the effluent active OHO concentration adds to the fixed ISS. The effluent active fraction of the VSS is 0.235 and the fraction of VSS removed is 0.352 . Hence, the effluent OHO concentration is $0.235(1-0.315) 1.42 \times 31500$ $=6807 \mathrm{mgOHOVSS} / \ell$, making its ISS contribution $=0.15 \mathrm{x}$ $6807=1021 \mathrm{mgISS} / \mathrm{l}$. The effluent ISS concentration thus is $10863+1021=11884 \mathrm{mgISS} / \mathrm{l}$. This is higher than the influent. The effluent VSS concentration is $(1-0.315) 31500 \times 1.42=$ $27911 \mathrm{mgVSS} / \mathrm{l}$, making the effluent VSS/TSS ratio 27911/ $(27911+11884)=0.701$.

In the calculations for aerobic digestion of PS above, the following is noted:

- COD is conserved, but not VSS. This is because the COD/ VSS ratio is different before and after OHO formation. For the example wastewater, the COD/VSS ratio for the PS before OHO formation $\left(\mathrm{f}_{\mathrm{cvPS}}\right)$ is 1.64. This is an average value of a $\left(1-f_{\text {PS }}\right)$ up to $f_{\text {PS'up }}$ mixture of biodegradable organics with a high COD/VSS ratio (1.71) and unbiodegradable organics with a COD/VSS ratio $f_{c v}=1.48 \mathrm{mgCOD} / \mathrm{mgVSS}$. After OHO VSS formation, the PS is similar to WAS with the same COD/VSS ratio $\left(\mathrm{f}_{\mathrm{cv}}\right)=1.48 \mathrm{mgCOD} / \mathrm{mgVSS}$ for both the OHO VSS and the unbiodegradable VSS, and with a defined active fraction with respect to VSS $\left(f_{\text {avPS }}\right)$. It may be argued that it is not necessary to use VSS in the steady state aerobic digester model and use COD throughout, as simulation models like ASM1 do. However, at some point the COD/VSS ratio of the sludge mass (and its components) is required in order to express the activated sludge concentrations as VSS or TSS to relate the model outputs to parameters commonly measured in practice at WWTPs. Whether this is at the beginning or end of the model calculations is irrelevant.

- The influent wastewater ISS that settles out in the PST is conserved through the aerobic digester (Ekama et al., 2006, Part 2). This ISS concentration can be determined by measurement on the primary sludge. However, the VSS/TSS ratio $\left(\mathrm{f}_{\mathrm{iPS}}\right)$ measured on the PS (before OHO formation i.e. $\mathrm{f}_{\mathrm{iPS}}=$ 0.83 , Table 1) changes to different values after OHO formation and during aerobic digestion of the PS. These changes arise from changes in both VSS and ISS concentrations during digestion due to the decreasing $\mathrm{OHO}$ concentration (see Fig. 5 in Ekama et al., 2006a, Part 2).

- Like for the COD/VSS ratio ( $f_{c v}$ ) (see above), it has been assumed in this analysis that the $\mathrm{N}$ (and P) contents of the VSS ( $f_{p}$ ) of the unbiodegradable organics (as VSS) in the PS are the same as activated sludge at $0.10 \mathrm{mgN} / \mathrm{mgVSS}$. Primary sludge characterisation with anaerobic digestion (Table 1, Wentzel et al., 2006, Part 1) indicates that for plantwide WWTP models, it will be necessary to assign different ratio values to the influent particulate unbiodegradable organics (and perhaps the endogenous residue) as the active (OHO) biomass to more accurately track the COD, VSS and $\mathrm{N}$ through the different unit operations of WWTPs. Activated Sludge Model No 2 (Henze et al., 1995) does this - it assigns 70, 40 and $30 \mathrm{mgN} / \mathrm{gCOD}$ to the $\mathrm{OHO}$ (and PAO) biomass, biodegradable particulate COD and unbiodegradable particulate organics respectively, but the experimental source for these ratios is not given. This aspect requires further investigation.

- The difference in COD/VSS ratio of the PS biodegradable and unbiodegradable organics does not affect the COD balance and aerobic digester model because all the biodegradable COD is transformed to OHO active VSS with a COD/ VSS ratio of $1.48 \mathrm{mgCOD} / \mathrm{mgVSS}$, the same as activated sludge. Similarly, the TKN/VSS (and TP/VSS) ratios of biodegradable (particulate) organics in PS are much lower than the measured average PS TKN/VSS $\left(\mathrm{f}_{\mathrm{nPS}}\right)\left(\right.$ and TP/VSS, $\left.\mathrm{f}_{\mathrm{pPS}}\right)$ ratios, but those of the $\mathrm{OHO}$ active VSS formed are the same as those of activated sludge, i.e. $f_{n}=0.100 \mathrm{mgN} / \mathrm{mgVSS}$ (and $\mathrm{f}_{\mathrm{p}}=0.030 \mathrm{mgP} / \mathrm{mgVSS}$ ).

\section{Aerobic digestion of PS and WAS blends - steady state modelling}

Aerobic digestion of blends of WAS and PS can be modelled with the equations and procedure developed for the two different sludges, but the blended sludge characteristics need to be defined. These are obtained from the individual WAS and PS characteristics. Like with PS only, the biodegradable COD in the PS is utilised in the aerobic digester and transformed to $\mathrm{OHO}$ 
active mass. The active fraction of the VSS mass formed and the synthesis oxygen demand in this process are given by Eqs. (1) and (2). The COD/VSS ratio ( $\left.f_{c v}\right)$ of the OHO VSS mass formed is $1.48 \mathrm{mgCOD} / \mathrm{mgVSS}$, the same as that of the WAS. This OHO VSS mass, as well as that in the WAS, is degraded via endogenous respiration (or death regeneration) in the aerobic digester in the identical way to WAS alone, as demonstrated for PS above. Like with PS only, the oxygen demand in the digester is the sum of the synthesis and endogenous oxygen demands, where now the latter is that by the OHOs from the PS and WAS.

The characteristics of the WAS and PS blend are obtained by adding the mass flows of like components in the WAS and PS and making ratios of selected blended mass flow rates to calculate the blended sludge characteristics. The process design of the digester is based on the blend characteristics after $\mathrm{OHO}$ VSS formation, such as active fraction with respect to VSS, the VSS/TSS ratio, and the fraction of PS VSS mass (after OHO formation) in the blend. This is demonstrated in Table 2, which lists the PS characteristics after OHO formation and before and after thickening to about $6 \%$ solids, and the WAS characteristics from the $8 \mathrm{~d}$ sludge age AS system treating the settled wastewater listed in Table 1, also before and after thickening to about $5 \%$ solids. The blended sludge characteristics are $\mathrm{f}_{\text {avi }}=0.619, \mathrm{f}_{\text {ati }}=$ 0.483 and $\mathrm{f}_{\mathrm{ii}}=0.782$.

Once the WAS equivalent blended sludge characteristics after OHO VSS formation are known, the WAS aerobic digestion model equations (marked with * below) apply (see Table 2 in Ekama et al., 2006a, Part 2), i.e. (1) for a specified effluent active fraction $\left(f_{a v e}\right)$, the retention time $\left(R_{h}\right)$ for a single reactor digester is given by Eq. $\left(3^{*}\right)$, and (2) the fraction of VSS solids removed and organic oxygen demand are given by Eqs. ( $\left.5^{*}\right)$ and $\left(6^{*}\right)$. The oxygen demand for synthesis of OHO mass from the PS biodegradable organics (Eq. (2)) is added to the endogenous oxygen demand. For example, with $\mathrm{f}_{\text {avi }}=0.619, \beta=0.816$ (Eq. $(2 *)$ ) and digesting the sludge to the same effluent active fraction as the WAS from the extended aeration (30 d sludge age) activated sludge system treating raw wastewater, i.e. $\mathrm{f}_{\text {ave }}=0.235$, yields $\alpha=1 / 0.235-0.8=3.455$ (Eq. $2^{*}$ ). Hence $\mathrm{R}_{\mathrm{h}}=16.0$ d (Eq. $\left(3^{*}\right)$ ), $\mathrm{f}_{\mathrm{vsr}}=0.378$ (Eq. $\left.\left(5^{*}\right)\right)$ and $\mathrm{V}_{\mathrm{d}} \mathrm{O}_{c}=1.48 \times 0.378 \times 0.089 \times 43065=$ $2146 \mathrm{kgO} / \mathrm{d}$ (Eq. (6*)). Adding the $1037 \mathrm{kgO} / \mathrm{d}$ synthesis oxygen demand gives the total oxygen demand $=2146+1037=$ $3183 \mathrm{kgO} / \mathrm{d}$. If a maximum OTR of $93 \mathrm{mgO} /(\mathrm{l} \cdot \mathrm{h})$ is accepted for the aeration system, then a digester volume of $3183 \times 1000 /(24$ $\mathrm{x} 93)=1430 \mathrm{~m}^{3}$ is required. With the fraction of VSS removed $\left(f_{v s r}\right)=0.378$, the effluent VSS concentration $=(1-0.378) 43065$ $=26786 \mathrm{mgVSS} / \mathrm{l}$. From the calculated $\mathrm{f}_{\text {ave }}, \mathrm{f}_{\text {ate }}$ and $\mathrm{f}_{\mathrm{ie}}(\mathrm{Eqs}$. $\left(21^{*}\right)$ and $\left.\left(22^{*}\right)\right)$, the different components of the digester effluent sludge can be calculated and are listed in Table 2 .

With WAS and PS blends, ammonia and phosphate dosages for non-nutrient deficient $\mathrm{OHO}$ growth are much lower than for $\mathrm{PS}$ alone or not required. This is because the $\mathrm{OHO}$ active mass in the WAS releases $\mathrm{N}$ and $\mathrm{P}$ to the bulk liquid during aerobic digestion. The released $\mathrm{N}$ can be readily nitrified in aerobic digesters stabilising blended PS and WAS sludges because the WAS is likely to contain nitrifiers. However, the contribution of the nitrification oxygen to the total generally will be low so it can be ignored when calculating the WAS and PS sludge thickening from the maximum OUR in the digester. For example, the ammonia and biodegradable organic nitrogen available in the PS for OHO synthesis, taking due account of PS thickening to $54 \mathrm{~m}^{3} / \mathrm{d}$, i.e. 1.38 times, is $(45+501 \times 1.38+1.7) 0.054=40.1$ $\mathrm{kgN} / \mathrm{d}$. The concentration of $\mathrm{N}$ required for $\mathrm{OHO}$ synthesis at $0.10 \mathrm{mgN} / \mathrm{mgVSS}$ is $0.10 \times 18634 \times 0.075=139.9 \mathrm{kgN} / \mathrm{d}$. The $\mathrm{N}$ released to the bulk liquid during endogenous respiration $=\mathrm{f}_{\mathrm{n}}$ $\mathrm{f}_{\mathrm{vs}} \mathrm{X}_{\mathrm{vi}} \mathrm{Q}_{\mathrm{i}}=0.10 \times 0.378 \times 43065 \times 0.089=144.9 \mathrm{kgN} / \mathrm{d}$. Hence, the net ammonia $\mathrm{N}$ released is $40.1-139.9+144.9=45.2 \mathrm{kgN} / \mathrm{d}$, which in a flow of $89 \mathrm{~m}^{3} / \mathrm{d}$ is $508 \mathrm{mgFSA}-\mathrm{N} / \mathrm{l}$. This FSA will be nitrified to nitrate. Adding the digester influent nitrate concentration from the WAS $(39.4 \mathrm{mgN} / \mathrm{\ell})$, appropriately diluted by the primary sludge flow to $39.4 \times 35 / 89=15.5 \mathrm{mgNO}_{3}-\mathrm{N} / \mathrm{l}$, yields an effluent nitrate concentration of $508+15=523 \mathrm{mgNO}_{3}-\mathrm{N} / \mathrm{l}$. This gives a nitrification oxygen demand of $213 \mathrm{kgO} / \mathrm{d}$, which is less than $10 \%$ of the carbonaceous oxygen demand. Because more $\mathrm{N}$ is released than required for growth, no $\mathrm{N}$ needs to be dosed in this case. The same would apply to P. The relatively high $\mathrm{N}$ (and P) content of the WAS supplies (overall) the $\mathrm{N}$ (and $\mathrm{P}$ ) requirement for a $\mathrm{OHO}$ synthesis on the PS biodegradable organics.

The results of the steady state model calculations for the two WWTP schemes in Fig. 1 are listed in Table 3a. From this table, it can be seen that the carbonaceous oxygen demand in both WWTPs are very closely the same (6 $944 \mathrm{vs.} 6941 \mathrm{kgO} / \mathrm{d}$ ) indicating that the steady state model and procedure developed for aerobic digestion of WAS and PS are correct.

\section{Aerobic digestion of PS and WAS blends - simulation with ASM1}

The primary purpose of the steady state models is to determine the reactor volumes, flow rates, sludge ages and oxygen requirements (or gas production) of the main biological reactor units making up the WWTP. Once these parameters have been determined to meet specified WWTP objectives, the individual units and WWTP as a whole (depending on complexity) can be modelled with simulation models to check their detailed performance and cyclic flow and load response. It is important therefore that simple steady state models, such as those developed and used in this series of four papers, yield results closely similar to the complex simulation ones. To compare the steady state AS and aerobic digestion model results with ASM1 (Henze et al., 1987), the two WWTPs above were simulated in Aquasim (Reichert, 1998) with ASM1, modified to include the ISS model of Ekama and Wentzel (2004). The simulated results are listed in Table $3 b$.

Comparing Tables $3 \mathrm{a}$ and $\mathrm{b}$, it can be seen that in all the important variables such as reactor VSS, TSS and ISS concentrations, active fractions, oxygen utilisation rates, VSS/TSS ratios, nitrate and TKN concentrations, the two models give virtually identical results. Also, and most importantly the COD, $\mathrm{N}$ and influent ISS balance to within $0.1 \%$ over both WWTP schemes with both models. The steady state aerobic digestion model therefore can be reliably included in a plant-wide steady state WWTP model with aerobic stabilisation of PS and WAS. Because the steady state anaerobic digestion (AD) model of Sötemann et al. (2005a) has been shown to give virtually the identical results as their dynamic simulation one (Sötemann et al. 2005b), and unbiodegradable organics in the influent wastewater and WAS remain unbiodegradable in the AD (Ekama et al., 2006b, Part 3), AD can replace aerobic digestion in the plantwide steady state and dynamic simulation WWTP models.

One aspect regarding simulation of the aerobic digester stabilising PS or PS/WAS blends needs to be mentioned. The ASM1 model was modified to include $\mathrm{OHO}$ growth processes using nitrate as N source (Dold and Marais, 1986; Dold et al., 1991). In completely mixed single aerobic reactor systems, the ammonia concentration is unlikely to be depleted sufficiently for $\mathrm{NO}_{3}^{-}$to be utilised as the $\mathrm{N}$ source - this situation is more likely to occur in plug flow type systems. In completely mixed 
TABLE 3a

COD and total $\mathrm{N}$ and ISS mass balances over two types of WWTP at $14^{\circ} \mathrm{C}$ (Figs. 1a and b)with the same final effluent residual biodegradable organic fraction of the final dewatered sludge $\left[\left(1-f_{E H}^{\prime}\right) f_{a v}=(1-0.08) 0.235=\right.$ 0.216 ] calculated with the steady state activated sludge and aerobic digestion model (Table $3 a$ ) and simulated with ASM1 modified to include the ISS model of Ekama and Wentzel (2004) (Table 3b).

\begin{tabular}{|c|c|c|c|c|c|c|c|c|c|c|c|}
\hline & & $\begin{array}{l}\text { Flow } \\
\mathrm{m}^{3} / \mathrm{d}\end{array}$ & $\begin{array}{l}\text { COD } \\
\mathrm{mg} / \mathrm{l}\end{array}$ & $\begin{array}{l}\text { COD } \\
\mathrm{kg} / \mathrm{d}\end{array}$ & $\begin{array}{c}\mathrm{N} \\
\mathrm{TKN} \\
\mathrm{mgN} / \ell \\
\end{array}$ & $\begin{array}{c}\mathrm{N} \\
\mathrm{NO3} \\
\mathrm{mgN} / \mathrm{l}\end{array}$ & $\begin{array}{c}\mathrm{TN} \\
\mathrm{kgN} / \mathrm{d}\end{array}$ & $\begin{array}{c}\text { ISS } \\
\text { ISSfixed } \\
\mathrm{mg} / \ell\end{array}$ & $\begin{array}{c}\text { ISS } \\
\text { ISSfixed } \\
\text { kg/d } \\
\end{array}$ & $\begin{array}{c}\text { ISS } \\
\text { ISSbio } \\
\mathrm{mg} / \ell\end{array}$ & $\begin{array}{c}\text { ISS } \\
\text { ISStotal } \\
\text { kg/d } \\
\end{array}$ \\
\hline 0 & Raw influent WW & 15000 & 750 & 11250 & 60 & 0 & 899.9 & 47.7 & 715.5 & 0 & 715.5 \\
\hline 1 & Raw WW 30 d & 15000 & 750 & 11250 & 60 & 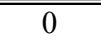 & 899.9 & 47.7 & 715.5 & 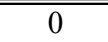 & $\overline{715.5}$ \\
\hline 1.1 & SST - effluent & 14218 & 53 & 754 & 1.8 & 42.3 & 627 & 0 & 0 & 0 & 0 \\
\hline \multirow[t]{3}{*}{1.2} & WAS - total & 782 & 4561 & 3567 & 306.4 & 42.3 & 272.7 & 914 & 714.7 & 107 & 798.4 \\
\hline & WAS - soluble & 782 & 53 & 42 & 1.8 & 42.3 & 34.5 & 0 & 0 & 0 & 0 \\
\hline & WAS - particulate & 782 & 4508 & 3591 & 304.6 & 0 & 238.2 & 914 & 714.7 & 107 & 798.4 \\
\hline 1.3 & $\begin{array}{l}\text { Carbon. oxygen demand } \\
(\mathrm{kgO} / \mathrm{d})\end{array}$ & & & 6944 & & & & & & & \\
\hline 1.4 & Total out $(\mathrm{kgCOD} / \mathrm{d})$ & & & 11265 & & & 899.7 & & 714.7 & & 798.4 \\
\hline 1.5 & $\%$ Mass balance & & & 100.1 & & & 99.9 & & 100 & & 111.6 \\
\hline 2 & Settled WW 8d & 14925 & 450 & 676716 & (51.1 & 0 & 762.7 & 9.5 & 141.8 & 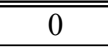 & 141.8 \\
\hline 2.1 & SST - effluent & 14482 & 53 & 767 & 1.8 & 39.4 & 596.7 & 0 & 0 & 0 & 0 \\
\hline \multirow[t]{3}{*}{2.2} & WAS - total & 443 & 4967 & 2200 & 333.8 & 39.4 & 165.3 & 320 & 141.8 & 330 & 288 \\
\hline & WAS - soluble & 443 & 53 & 24 & 1.8 & 39.4 & 18.3 & 0 & 0 & 0 & 0 \\
\hline & WAS - particulate & 443 & 4914 & 2177 & 332 & 0 & 147.1 & 320 & 141.8 & 330 & 288 \\
\hline 2.3 & $\begin{array}{l}\text { Carbon. oxygen demand } \\
(\mathrm{kgO} / \mathrm{d})\end{array}$ & - & & 3758 & & & & & & & \\
\hline 2.4 & Total out $(\mathrm{kgCOD} / \mathrm{d})$ & & & 6725 & & & 762 & & & & \\
\hline \multirow[t]{3}{*}{3} & PS - total & 75 & 60450 & 44534 & 1833.1 & 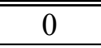 & 137.5 & 76650 & $\begin{array}{l}573.7 \\
\end{array}$ & 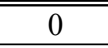 & 573.7 \\
\hline & PS - soluble & 75 & 199 & 15 & 48.5 & 0 & 3.6 & 0 & 0 & 0 & 0 \\
\hline & PS - particulate & 75 & 60251 & 4519 & 1784.6 & 0 & 133.8 & 7650 & 573.7 & 0 & 573.7 \\
\hline 4 & WAS thickener effluent & 408 & 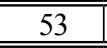 & 22 & 1.8 & 39.4 & 16.8 & 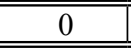 & 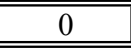 & 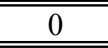 & 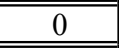 \\
\hline$\overline{5}$ & Gravity thick effluent & 21 & 199 & $\begin{array}{l}4 \\
\end{array}$ & 48.5 & "0 & 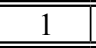 & "0 & "0 & "0 & "0 \\
\hline \multirow[t]{3}{*}{6.1} & $\begin{array}{l}\text { Aerobic digester influent } \\
\text { - total }\end{array}$ & 89 & "75367 & 6708 & 3183 & 15.5 & 285 & 8039 & 715.5 & (3998* & 1071.3* \\
\hline & $\begin{array}{l}\text { Aerobic digester influent } \\
\text { - soluble }\end{array}$ & 89 & 142 & 13 & 29.1 & 15.5 & 4 & 0 & 0 & 0 & 0 \\
\hline & $\begin{array}{l}\text { Aerobic digester influent } \\
\text { - Particulate }\end{array}$ & 89 & 75225 & 6695 & 3154 & 0 & 281 & 8039 & 715.5 & $3998^{*}$ & $1071.3^{*}$ \\
\hline \multirow[t]{3}{*}{6.2} & $\begin{array}{l}\text { Aerobic digester effluent } \\
\text { - Total }\end{array}$ & 89 & 39687 & 3532 & 2681 & 523 & 285.1 & 8040 & 715.6 & 944 & 800 \\
\hline & $\begin{array}{l}\text { Aerobic digester effluent } \\
\text { - Soluble }\end{array}$ & 89 & 53 & 5 & 1.8 & 523 & 46.7 & 0 & 0 & 0 & 0 \\
\hline & $\begin{array}{l}\text { Aerobic digester effluent } \\
\text { - Particulate }\end{array}$ & 89 & 39644 & 3527 & 2679 & 0 & 238.4 & 8040 & 715.6 & 944 & 800 \\
\hline 6.3 & $\begin{array}{l}\text { Carbon. oxygen demand } \\
(\mathrm{kgO} / \mathrm{d})\end{array}$ & & & 3183 & & & & & & & \\
\hline 6.4 & $\begin{array}{l}\text { Aerobic digester out - total } \\
(\mathrm{kgCOD} / \mathrm{d})\end{array}$ & & & 6715 & & & 285.1 & & 715.6 & & 800 \\
\hline 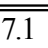 & Total out in water flows & & & 44320 & & & 899.6 & & 715.6 & & 800 \\
\hline 7.2 & $\begin{array}{l}\text { Total carbon. oxygen } \\
\text { demand }(\mathrm{kgO} / \mathrm{d})\end{array}$ & & & 6941 & & & & & & & \\
\hline 8.1 & Total out of WWTP & & & 11261 & & & 899.6 & & 715.6 & & 800 \\
\hline 8.2 & $\%$ mass balance & & & 100.1 & & & 99.9 & & 100 & & 111.8 \\
\hline
\end{tabular}

nitrifying aerobic digestion of waste activated sludge there always should be sufficient ammonia for growth because the ammonia released in $\mathrm{OHO}$ death always is greater than that taken up for $\mathrm{OHO}$ growth on the slowly biodegradable (SB) COD released in $\mathrm{OHO}$ death. However, in application of the model, nitrate utilisation for $\mathrm{OHO}$ growth nevertheless can occur. This can also occur with model application to aerobic digestion of primary sludge even when sufficient ammonia is dosed for net $\mathrm{OHO}$ biomass production from the PS particulate biodegradable organics. This apparent ammonia deficiency in the model arises because the rate of nitrification is faster than the rate of $\mathrm{OHO}$ growth, which is limited by the supply rate of SBCOD from the OHO death process. This leads to uptake of nitrate for $\mathrm{OHO}$ growth, but the release of ammonia in $\mathrm{OHO}$ 


\begin{tabular}{|c|c|c|c|c|c|c|c|c|c|c|c|}
\hline \multicolumn{12}{|c|}{$\begin{array}{l}\text { TABLE } 3 b \\
\left.\text { COD and total } N \text { and ISS mass balances over two types of WWTP at } 14^{\circ} \mathrm{C} \text { (Figs. 9a and } b\right) \text { with the same final } \\
\text { effluent residual biodegradable organic fraction of the final dewatered sludge }\left[\left(1-f_{\mathrm{EH}}^{\prime}\right) f_{\mathrm{av}}=(1-0.08) 0.235=\right. \\
0.216] \text { calculated with the steady state activated sludge and aerobic digestion model (Table } 3 \mathrm{a}) \text { and } \\
\text { simulated with ASM1 modified to include the ISS model of Ekama and Wentzel (2004) (Table } 3 \mathrm{~b}) \text {. }\end{array}$} \\
\hline & & $\begin{array}{l}\text { Flow } \\
\mathrm{m}^{3} / \mathrm{d}\end{array}$ & $\begin{array}{l}\text { COD } \\
\mathrm{mg} / \mathrm{l}\end{array}$ & $\begin{array}{l}\text { COD } \\
\mathrm{kg} / \mathrm{d}\end{array}$ & $\begin{array}{c}\mathbf{N} \\
\mathrm{TKN} \\
\mathrm{mgN} / \ell\end{array}$ & $\begin{array}{c}\mathrm{N} \\
\mathrm{NO3} \\
\mathrm{mgN} / \ell\end{array}$ & $\begin{array}{c}\mathrm{TN} \\
\mathrm{kgN} / \mathrm{d}\end{array}$ & $\begin{array}{c}\text { ISS } \\
\text { ISSfixed } \\
\text { mg/l }\end{array}$ & $\begin{array}{l}\text { ISS } \\
\text { ISSfixed } \\
\text { kg/d }\end{array}$ & $\begin{array}{c}\text { ISS } \\
\text { ISSbio } \\
\mathrm{mg} / \mathrm{l}\end{array}$ & $\begin{array}{c}\text { ISS } \\
\text { ISStotal } \\
\mathrm{kg} / \mathrm{d}\end{array}$ \\
\hline 0 & Raw influent WW & 15000 & 750 & 11250 & 60 & 0 & 899.9 & 47.7 & 715.5 & 0 & 715.5 \\
\hline 1 & Raw WW 30 d & 015000 & $7 \overline{750}$ & 111250 & 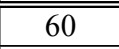 & 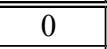 & 899.9 & $\begin{array}{l}47.7 \\
\end{array}$ & 715.5 & 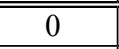 & 7115.5 \\
\hline 1.1 & SST - effluent & 14218 & 53 & 754 & 3.3 & 40.3 & 619.9 & 0 & 0 & 0 & 0 \\
\hline \multirow[t]{3}{*}{1.2} & WAS - total & 782 & 4587 & 3633 & 309.2 & 40.3 & 276.8 & 903 & 715.2 & 103 & 796.8 \\
\hline & WAS - soluble & 782 & 53 & 42 & 3.3 & 40.3 & 34.5 & 0 & 0 & 0 & 0 \\
\hline & WAS - particulate & 782 & 4534 & 3591 & 305.9 & 0 & 242.3 & 903 & 715.2 & 103 & 796.8 \\
\hline 1.3 & $\begin{array}{l}\text { Carbon. oxygen } \\
\text { demand }(\mathrm{kgO} / \mathrm{d})\end{array}$ & & & 6903 & & & & & & & \\
\hline 1.4 & Total out $(\mathrm{kgCOD} / \mathrm{d})$ & & & 11289 & & & 897 & & 715 & & 797 \\
\hline 1.5 & $\%$ Mass balance & & & 100.4 & & & 99.7 & & 100 & & 111.4 \\
\hline 2 & Settled WW 8d & 14925 & 450 & 6716 & 51.1 & 0 & 762.4 & 9.5 & 141.8 & 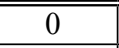 & 141.8 \\
\hline 2.1 & SST - effluent & 14482 & 54 & 781 & 4.3 & 36.2 & 586.5 & 0 & 0 & 0 & 0 \\
\hline \multirow[t]{3}{*}{2.2} & WAS - total & 443 & 4968 & 2201 & 344.4 & 36.2 & 168.6 & 320.2 & 141.8 & 326.4 & 286.4 \\
\hline & WAS - soluble & 443 & 54 & 24 & 4.3 & 36.2 & 17.9 & 0 & 0 & 0 & 0 \\
\hline & WAS - particulate & 443 & 4914 & 2177 & 340.1 & 0 & 150.7 & 320.2 & 141.8 & 326.4 & 286.4 \\
\hline 2.3 & $\begin{array}{l}\text { Carbon. oxygen } \\
\text { demand }(\mathrm{kgO} / \mathrm{d})\end{array}$ & - & & 3700 & & & & & & & \\
\hline 2.4 & Total out $(\mathrm{kgCOD} / \mathrm{d})$ & & & 6681 & & & 755.1 & & & & \\
\hline \multirow[t]{3}{*}{\begin{tabular}{|l|}
3 \\
\end{tabular}} & PS - total & 75 & 60450 & 4534 & 1833.1 & 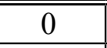 & 137.5 & 7650 & 573.7 & 0 & 573.7 \\
\hline & PS - soluble & 75 & 199 & 15 & 48.5 & 0 & 3.6 & 0 & 0 & 0 & 0 \\
\hline & PS - particulate & 75 & 60251 & 4519 & 1784.6 & 0 & 133.8 & 7650 & 573.7 & 0 & 573.7 \\
\hline 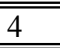 & WAS thickener effluent & 408 & 54 & 22 & 4.3 & 36.2 & 16.5 & 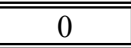 & 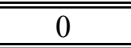 & 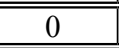 & 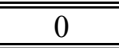 \\
\hline 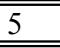 & Gravity thick effluent & 21 & 199 & 4 & 48.5 & 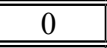 & 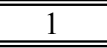 & 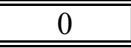 & 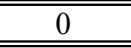 & 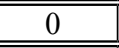 & 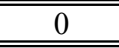 \\
\hline \multirow[t]{3}{*}{6.1} & $\begin{array}{l}\text { Aerobic digester influ- } \\
\text { ent - total }\end{array}$ & 89 & 254110 & 48803 & 171786 & 14.3 & 159.8 & 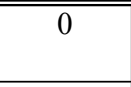 & 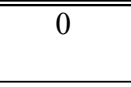 & 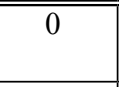 & 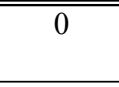 \\
\hline & $\begin{array}{l}\text { Aerobic digester influ- } \\
\text { ent - soluble }\end{array}$ & 89 & 142 & 13 & 31.1 & 14.3 & 4 & 0 & 0 & 0 & 0 \\
\hline & $\begin{array}{l}\text { Aerobic digester influ- } \\
\text { ent - Particulate }\end{array}$ & 89 & 53969 & 4790 & 1755 & 0 & 155.8 & 0 & 0 & 0 & 0 \\
\hline \multirow[t]{3}{*}{6.2} & $\begin{array}{l}\text { Aerobic digester efflu- } \\
\text { ent - Total }\end{array}$ & 89 & 39928 & 3544 & 2721.4 & 521.7 & 287.9 & 8021 & 711.9 & 945.6 & 795.9 \\
\hline & $\begin{array}{l}\text { Aerobic digester efflu- } \\
\text { ent }- \text { Soluble }\end{array}$ & 89 & 53 & 5 & 3.1 & 521.7 & 46.6 & 0 & 0 & 0 & 0 \\
\hline & $\begin{array}{l}\text { Aerobic digester efflu- } \\
\text { ent - Particulate }\end{array}$ & 89 & 39875 & 3539 & 2718.3 & 0 & 241.3 & 8021 & 711.9 & 945.6 & 795.9 \\
\hline 6.3 & $\begin{array}{l}\text { Carbon. oxygen } \\
\text { demand }(\mathrm{kgO} / \mathrm{d})\end{array}$ & & & 3195 & & & & & & & \\
\hline 6.4 & $\begin{array}{l}\text { Aerobic digester out } \\
- \text { total }(\mathrm{kgCOD} / \mathrm{d})\end{array}$ & & & 6739 & & & 287.9 & & 711.9 & & 795.9 \\
\hline 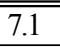 & Total out in water flows & & & $4 \quad 4351$ & & & 891.9 & & 711.9 & & 79795.9 \\
\hline 7.2 & $\begin{array}{l}\text { Total carbon. oxygen } \\
\text { demand }(\mathrm{kgO} / \mathrm{d})\end{array}$ & & & 6895 & & & & & & & \\
\hline 8.1 & Total out of WWTP & & & 11246 & & & 891.9 & & 711.9 & & 795.9 \\
\hline 8.2 & $\%$ mass balance & & & 100 & & & 99.1 & & 99.5 & & 111.2 \\
\hline
\end{tabular}

death. This released ammonia is then nitrified with an associated OUR for nitrification. The consequence is an incorrectly predicted high nitrification OUR from the continual supply of ammonia nitrogen from the death process, nitrogen that is taken up as nitrate by the OHOs in the growth process. This problem is eliminated in the model by reducing the switching function $\mathrm{K}$ value which controls the switch from ammonia to nitrate uptake for OHO growth to a very low value $(0.0001 \mathrm{mgN} / \ell)$. This prevents the $\mathrm{OHO}$ growth process from slowing down when the ammonia concentration gets low, allowing it to successfully "compete" for ammonia against the nitrification process. This problem of nitrate utilisation for growth therefore has nothing to do with ammonia deficiency but everything to do with the relative rates of processes competing for the same compounds, 
in this case ammonium $\left(\mathrm{NH}_{4}^{+}\right)$. $\mathrm{K}$ values of switching functions on processes competing for the same compounds therefore require very careful scrutiny in simulation models.

\section{Conclusions}

From the investigation in this series of four papers (Wentzel et al., 2006, Part 1; Ekama et al., 2006a,b, Parts 2 and 3) of the continuity of wastewater organic, $\mathrm{N}$ and inorganic suspended solids (ISS) compounds along the links connecting the primary settling tank (PST), fully aerobic or $\mathrm{N}$ removal activated sludge (AS) and anaerobic and aerobic digestion unit operations, the conclusions can be summarised as follows:

- Application of the COD, carbon (C) and nitrogen (N) mass balance steady state anaerobic digestion (AD) model of Sötemann et al. (2005a) to literature data of AD of primary sludge (PS) and waste activated sludge (WAS) showed that this model satisfactorily predicted AD performance for both sludge types (gas production and composition, effluent COD, free and saline ammonia and alkalinity concentrations) and provided a mass balance-based structure to determine the unbiodegradable particulate organic (COD) fraction of PS ( $\left.\mathrm{f}_{\mathrm{PS} \text { up }}\right)$ and WAS $\left(\mathrm{f}_{\mathrm{AS} \text { up }}\right)$. The unbiodegradable particulate COD fraction of PS $\left(\mathrm{f}_{\mathrm{PS} \text { 'up }}\right)$ determined from the AD model matched very closely that calculated for PS from a mass balance around the PST for typical raw and settled wastewater characteristics. Also, the unbiodegradable particulate COD fraction of WAS $\left(\mathrm{f}_{\mathrm{AS} \text { up }}\right)$ determined from the AD model matched very closely that calculated for WAS from the steady state activated sludge model of Marais and Ekama (1976) and WRC (1984), provided the unbiodegradable fraction of the ordinary heterotrophic organisms (OHOs) is assigned the value from the deathregeneration model $\left(\mathrm{f}_{\mathrm{EH}}{ }^{\prime}=0.08\right)$, not the value from the net effect endogenous respiration model $\left(\mathrm{f}_{\mathrm{EH}}=0.20\right)$.

- It follows from the above that:

- the PS characteristics need to be calculated from mass balances around the PST so that the organic (COD) and $\mathrm{N}$ concentrations and components, viz. biodegradable and unbiodegradable, soluble and particulate, conform to continuity principles,

- the influent unbiodegradable particulate organics determined from response of the activated sludge system are also unbiodegradable under anaerobic digestion conditions,

- the unbiodegradable particulate organics that are generated in the activated sludge reactor, i.e. endogenous residue, also are unbiodegradable under anaerobic digester conditions and

- the residual biodegradable particulate organics that can be anaerobically digested can be calculated from the active fraction of the WAS using the widely accepted stoichiometric and kinetic constants in AS models such as ASM1 (Henze et al., 1987).

- Anaerobic digestion of PS provides a basis to determine the COD/VSS and N/COD ratios of the influent wastewater biodegradable and unbiodegradable particulate organics. From data from several anaerobic digester studies, it was found that the COD/VSS $\left(f_{c y}\right)$ and N/COD $\left(\mathrm{f}_{\mathrm{ZBN}}\right)$ ratios of influent unbiodegradable particulate organics $\left(\mathrm{S}_{\mathrm{upi}}\right)$ are significantly higher than the ratios for biodegradable particulate organics $\left(\mathrm{S}_{\mathrm{bpi}}\right)$. For example - the N/COD ratio of unbiodegradable particulate organics was found to be four times higher ( $\sim 40 \mathrm{mgN} / \mathrm{gCOD}$ ) than for biodegradable particulate organics ( $\sim 10 \mathrm{mgN} / \mathrm{gCOD})$. Also, the COD/VSS and N/COD ratios for unbiodegradable particulate organics are significantly different to the ratios commonly assumed for these organics in activated sludge models, viz. $\mathrm{f}_{\mathrm{cv}}=1.48$ $\mathrm{mgCOD} / \mathrm{mgVSS}$ and $\mathrm{f}_{\mathrm{ZB}, \mathrm{N}}=67.6 \mathrm{mgN} / \mathrm{gCOD}\left(\mathrm{f}_{\mathrm{n}}=0.10\right.$ $\mathrm{mgN} / \mathrm{mgVSS}$ ). While these differences in the ratios make little difference to the activated sludge system as a stand alone operation, they are significant when tracking COD, VSS and N fluxes through a network of unit operations of a WWTP. Different N/COD ratios for biodegradable and unbiodegradable particulate organics have been incorporated in ASM2 (Henze et al., 1995), but the experimental basis for the listed values ( 40 and $30 \mathrm{mgN} / \mathrm{gCOD}$ respectively) are not given. This aspect requires a further exploration in the context of plant-wide WWTP models.

- From the experimental data in several literature sources, it is reasonable to accept that the influent wastewater (fixed) ISS concentration is conserved through activated sludge and aerobic digestion systems. However, the measured ISS flux at different stages through a series of WWTP unit operations is not equal to the influent ISS flux. The OHO biomass contributes to the fixed ISS flux by differing amounts depending on the active fraction of the VSS solids. The ISS model of Ekama and Wentzel (2004), which assigns an ISS content to OHOs of $0.15 \mathrm{mgISS} /$ mgOHOVSS, correlates very well with experimental data from a WWTP comprising an aerated lagoon and four inseries aerobic digesters. This not only provides additional validation for the ISS model, but also shows that it can be used for tracking the ISS through activated sludge and aerobic digester systems down to very low active fractions. The data on conservation of influent ISS in PS and WAS anaerobic digestion are variable and from the data evaluated, it could not be concluded that influent ISS is conserved.

- The COD/VSS and N/COD ratios obtained for the WAS biodegradable and unbiodegradable organics appear to be similar in magnitude and close to the commonly accepted ratios for activated sludge (COD/VSS $=1.48 \mathrm{mgCOD} / \mathrm{mgVSS}$ and $\mathrm{N} / \mathrm{COD}=67.6 \mathrm{mgN} / \mathrm{gCOD}$ or $\mathrm{f}_{\mathrm{n}}=0.10 \mathrm{mgN} / \mathrm{mgVSS}$ ) and the variations observed in these ratios in this investigation seem to be mostly due to experimental error. Therefore, it seems reasonable to assign these ratio values to the $\mathrm{OHO}$ biomass and endogenous residue.

- An aspect only peripherally considered in this series of four papers is the carbon $(\mathrm{C})$ balance over the WWTP. While the $\mathrm{C}$ balance is not important for the activated sludge system itself, the C content of PS and WAS is important for anaerobic digestion. From one data set on anaerobic digestion of WAS, the CHON stoichiometric composition of the biodegradable organics of the WAS was determined from chemical and elemental analysis to be $\mathrm{C}_{3.691} \mathrm{H}_{7.0} \mathrm{O}_{1.99} \mathrm{~N}_{0.503}$, which yielded a reasonable correlation between calculated and measured AD performance. Although this WAS stoichiometry seems to differ quite widely from $\mathrm{C}_{4.80} \mathrm{H}_{7.0} \mathrm{O}_{2.0} \mathrm{~N}_{0.77}$, it makes relatively little difference to the digester effluent and gas streams per COD load. The CHON stoichiometry of AD of wastewater organics can be modified and applied to nitrification denitrification activated sludge to include this system in the $\mathrm{C}$ balance over the WWTP. This, and the feasibility of developing approximate $\mathrm{CHON}$ stoichiometric formu- 
lae for the different influent wastewater organic fractions will be explored in further research to try to complete the C balance over the WWTP.

- The steady state aerobic digester model developed for stabilisation of WAS was found to correlate very well with literature data. This model can also be applied to model aerobic digestion of PS and PS-WAS blends. To use the model requires the equivalent influent active fraction of the PS to be calculated. This influent active fraction can be calculated from the biodegradable COD fraction of the PS determined from a mass balance around PST (see above).

- The steady state activated sludge and aerobic digestion models were applied to two WWTP schemes treating the same raw wastewater - one comprising PST, short sludge age activated sludge and aerobic digestion of PS-WAS blend, the other a long sludge age extended aeration activated sludge system. The models were found to yield COD, N and influent ISS mass balances within $0.1 \%$ and gave almost identical results for the two WWTP schemes for the same final residual biodegradable COD fraction. Also, for both WWTP schemes, the steady state models gave virtually identical results to ASM1 and therefore can be used to check simulation model outputs.

This research has indicated that the mass balance-based steady state activated sludge, aerobic digestion and anaerobic digestion models, modified to include the ISS compound, provide internally consistent and externally compatible elements that can be coupled to produce an integrated steady state model for the whole WWTP. Not considered in this series of four papers were phosphorus, phosphorus accumulating organisms (PAOs) and biological excess P removal (BEPR) plants. The PAOs introduce several complex issues which require further investigation e.g. in the BEPR system, the ordinary heterotrophic organisms (OHO) and PAOs have different endogenous respiration/die off rates, the former high $\left(b_{\mathrm{H} 20}=0.24 / \mathrm{d}\right.$ at $\left.20^{\circ} \mathrm{C}\right)$ and the latter low $\left(b_{\mathrm{G} 20}=0.04 / \mathrm{d}\right.$ at $\left.20^{\circ} \mathrm{C}\right)$. These $\mathrm{b}$ rates influence the rates at which the nutrients $\mathrm{N}$ and $\mathrm{P}$ bound in the cell mass are released in aerobic and anaerobic digestion. The release rates of $\mathrm{N}$ and $P$ from the solid cell bound phase to the dissolved phase under aerobic and anaerobic digestion conditions needs to be investigated to include P and BEPR systems into plant-wide WWTP models.

\section{Acknowledgments}

This research was supported by the Water Research Commission, the National Research Foundation and the University of Cape Town and is published with their permission.

\section{References}

DOLD PL and MARAIS GvR (1986) Evaluation of the general activated sludge model proposed by the IAWPRC Task Group. Water Sci. Technol. 18 (6) 63-89.

DOLD PL, WENTZEL MC, BILLING AE, EKAMA GA and MARAIS GvR (1991) Activated Sludge Simulation Programs. WRC Report No TT 52/91, Water Research Commission, Private Bag X03, Gezina, 0031, South Africa.

EKAMA G.A. and WENTZEL M.C. (2004) Modelling inorganic material in activated sludge systems. Water SA 30 (2) 153-174.

EKAMA GA, WENTZEL MC and SÖTEMANN SW (2006a) Mass balance-based plant-wide wastewater treatment plant models - Part 2: Tracking the influent inorganic suspended solids. Water $S A 32$ (3) $277-286$

EKAMA GA, SÖTEMANN SW and WENTZEL MC (2006b) Mass balance-based plant-wide wastewater treatment plant models - Part 3: Biodegradability of activated sludge organics under anaerobic conditions. Water SA 32 (3) 287-296.

HENZE M, GRADY CPL (Jr), GUJER W, MARAIS GvR and MATSUO T (1987) Activated Sludge Model No 1. IWA Scientific and Technical Report No 1, IWA London. ISSN 1010-707X. 33 pp.

HENZE M, GUJER W, MINO T, MATSUO T, WENTZEL MC and MARAIS GvR (1995) Activated Sludge Model No 2. IWA Scientific and Technical Report No 3, IWA London. ISBN 1-900222-00-0. 32 pp.

MARAIS GvR and EKAMA GA (1976) The activated sludge process Part 1 - Steady state behaviour. Water SA 2 (4) 163-200.

REICHERT P (1998) Aquasim 2.0 - Computer Program for the Identification and Simulation of Aquatic Systems. EAWAG, Dubendorf CH-8600 Switzerland, ISBN 3-906484-17-3.

SÖTEMANN SW, RISTOW NE, WENTZEL MC and EKAMA GA (2005a) A steady state model for anaerobic digestion of sewage sludges. Water SA 31 (4) 511-527.

SÖTEMANN SW, VAN RENSBURG P, RISTOW NE, WENTZEL MC, LOEWENTHAL RE and EKAMA GA (2005b) Integrated chemical, physical and biological processes modelling Part 2 - Anaerobic digestion of sewage sludges. Water SA 31 (4) 545-568.

WENTZEL MC, EKAMA GA and SÖTEMANN SW (2006) Mass balance-based plant-wide wastewater treatment plant models - Part 1: Biodegradability of wastewater organics under anaerobic conditions. Water SA 32 (3) 269-276.

WRC (1984) Theory, Design and Operation of Nutrient Removal Activated Sludge Processes. Wiechers HNS (ed.), WRC Report No TT 16/84. Water Research Commission, Private Bag X03, Gezina, 0031, RSA. ISBN 0908356137. 